\title{
AZ ELTÉRÉSI NEGATIVITÁS MÉRÉSI-ÚJRAMÉRÉSI MEGBÍZHATÓSÁGA ${ }^{1}$
}

\author{
SZÜCS DÉNES-SÜLE JUDIT
}

ELTE, Bölcsészettudományi Kar, Kísérleti Pszichológia Tanszék

E-mail: sdini@cogpsyphy.hu

\section{CSÉPE VALÉRIA}

ELTE, Bölcsészettudományi Kar, Kísérleti Pszichológia Tanszék MTA Pszichológiai Kutatóintézete, Pszichofiziológiai Osztály

E-mail: csepe@cogpsyphy.hu

Kisérletünkben azt vizsgáltuk, hogy mennyire megbizhatóan azonositható a hallási eseményhez kötött potenciálok jellegzetes összetevõje, az Eltérési Negativitás (EN) ismételt klinikai mérések sorozatában (mérési-újramérési megbizhatóság) különbözö ingertípusok használata esetén.

Tiz egészséges fiatal felnött kísérleti személyben tiszta hang, magánhangzó és mássalhangzómagánhangzó ingerekkel váltottunk ki EN-t. Valamennyi ingertípus esetében egy standard (megjelenési valószinüsége: 70\%) és két deviáns (15-15\%) ingert alkalmaztunk. A személyek 5 kisérleti ülésen vettek részt, amelyek egy-négy napos idóközönként követték egymást. A csoportátlagban az EN valamennyi ingerlési feltételben és valamennyi ülésben megbizhatóan megjelent. Az egyéni EN-válaszban nagy különbségeket tapasztaltunk. Az egyéni adatelemzés során a különbséggörbéken -0,5 $\mu \mathrm{V}$-nál pozitívabb csúcsamplitúdójú válaszokat nem tekintettük EN-nek. Ilyen kritériumszint mellett az EN egyéni elfogadása 64-90\% (átlagosan: 81\%) között alakult. Az egyes ingertípusok megbizhatósága között nem találtunk statisztikailag szignifikáns különbséget. Az EN megbízhatósága a standard ingerek arányának emelésével és az ingertípus gondos megválasztásával nagy valószínüséggel tovább fokozható.

Kulcsszavak: eltérési negativitás, automatikus ingerfeldolgozás, újramérési megbizhatóság, habituáció, szenzitizáció

A kutatás az OTKA T019875, valamint T033008 számú pályázat támogatásával (témavezető: Csépe Valéria) valósult meg.

Köszönjük a rovatvezetőnek és a lektoroknak a kézirat jobbítását nagyban elősegítő alapos és gondos tanácsait.

1 A közlemény anyaga részben elhangzott a XXIII. Országos Tudományos Diákköri Konferencián. 


\section{BEVEZETÉS}

\section{Az Eltérési Negativitás (EN)}

A hallási eseményhez kötött potenciálok (EKP-ok) jellegzetes komponense az Eltérési Negativitás. Az EN akkor jelenik meg, ha viszonylag ritka (deviáns) hallási inger töri meg a nagyobb valószínűséggel előforduló (gyakori, standard) ingerek sorozatát (NÄÄTÄNEN és munkatársai, 1978). Az EN-t tehát nem önmagukban az ingerparaméterek, hanem a standard és deviáns ingerek fizikai paramétereinek eltérései váltják ki. Az EN-t kiválthatja a standard és deviáns ingerek frekvenciájának, intenzitásának, téri helyének, tartamának, fonetikus szerkezetének stb. eltérése (összefoglalásul lásd: NÄÄTÄNEN, 1992).

Az EN latenciája általában 120-250 ms közötti. Az EN-t kiváltó eltérés nagysága körülbelül megegyezik a szubjektív diszkriminációs képességgel (NÄÄTäNEN, 1995). Az EN mérhető paramétereit (amplitúdó, latencia, eloszlás) számos tényező befolyásolja, így például az ingerek közötti időtartam (ISI), a deviáns inger valószínüsége (SAMS és munkatársai, 1983), a deviáns és standard ingerek fizikai jellemzői (például frekvencia, intenzitás) közötti különbség mértéke (NÄÄTÄNEN, 1990).

Az EN egyaránt kiváltható figyelmi és nem figyelt helyzetben, illetve csatornán. A figyelem teljes hiánya nem vezet az EN megszűnéséhez, a fókuszált figyelem hatása azonban megváltoztathatja a hullám jellemzőit (NÄÄTÄNEN, ALHO, 1997). Aktív (figyelmi) helyzetben számolnunk kell azzal, hogy az EN összegződik két jellegzetes endogén figyelmi hullámmal, az N2b-vel és a P3-mal (NÄÄTÄNEN, 1995). A legtisztább EN válasz passzív (nem figyelmi) helyzetben vezethető el. Ekkor is számolni kell az N1 és P2 hullámok esetleges torzító hatásával, ez a hatás azonban korántsem olyan számottevő, mint a figyelmi hatások.

Csak azokra a deviáns ingerekre váltható ki EN, amelyek a standard ingerek megjelenése utáni 5-10 másodpercen belül érkeztek (NÄÄTÄNEN, 1990). Úgy tünik, hogy egy rövid távú, a standard ingert reprezentáló memórianyomnak kell kiépülnie ahhoz, hogy az idegrendszer elvégezhesse a standard és deviáns ingerek összevetését (COWAN és munkatársai, 1993). A memórianyom olyan „időben elmozduló integrációs ablakként" képzelhető el, amely nagyjából a legutolsó $200 \mathrm{~ms}$ elemi akusztikus történéseit gyüjti össze (NÄÄTÄNEN, 1992). Az EN olyan folyamat velejárója, amely alapját képezheti a figyelmi váltásnak, önmagában azonban nem eredményez ilyet (NäÄTÄNEN, 1986).

NÄÄTÄnen, Schröger, Karakas, TERVANiemi és PAAVILAineN (1993) igen finom hangzási különbségekkel (összetett hangmintázatokkal) váltottak ki EN-t. Számos kísérleti alanynál finom különbségekre nem jelentkezett EN, és szubjektív élménye sem volt a kísérleti személyeknek a különbségrỏl. A kísérleti ülések végére lassanként elkezdték hallani a hangok közti különbséget, s ezzel párhuzamosan az EN is megjelent náluk. E jelenség magyarázható oly módon, hogy az emlékezetben kialakultak az eltérô hangokat reprezentáló, a különbségészlelés számára is használható memórianyomok. Az említett különbségészlelés képessége és a rá jellemző EN-válasz csökkent mértékben ugyan, de a következő ülésekre is fennma- 
radt, azaz a hosszú távú emlékezetben is kiépültek a finom hangzásbeli különbségek elkülönítésében használható memórianyomok. KRAUS, MCGEE, CARREL és SHARMA (1995) hasonló kiindulású kísérletének eredménye szerint a hallórendszer plasztikussága nemcsak a tiszta hangokra, hanem a fonémákra adott ENválaszokban is határozottan jelentkezik, és ezek a tapasztalatfüggő változások jól demonstrálhatók az EN-válasz változásaival.

\section{Az EN klinikai alkalmazása}

A beszéd komplex és dinamikus akusztikus jelekből áll, a beszédpercepció pedig ezen folyamatos akusztikus változások észlelését igényli. Az éppen a finom akusztikus változásokra érzékeny EN mögött álló folyamatok minden bizonnyal igen nagy szerepet játszanak ebben a komplex feldolgozásban. A beszédpercepcióval mutatott szoros összefüggése miatt az EN a klinikai gyakorlatban sok területen diagnosztikai szerepet tölthet be, illetve megfelelö eszköz lehet az alkalmazott fejlesztő módszerek hatékonyságának ellenőrzésében.

Az EN klinikai alkalmazásának lehetőségeit jelenleg még alapkutatási szakaszban vizsgálják. Az eddigi eredmények igen biztatóak, sokrétű felhasználási lehetőséget ígérnek (áttekintésként lásd: CsÉPE, MOLNÁR, 1997). A potenciális klinikai felhasználási lehetőségek korábbi kísérleti eredményekre alapozhatók. Az EN válasz jellegének elemzése alkalmas lehet az agykéreg általános funkcionális állapotának feltárására. Az integráltabb, „jobb működésű”, nagyobb vigilanciájú agyi állapotokat az EN nagyobb amplitúdójú megjelenése jellemzi (LANG és munkatársai, 1995). Különösen jelentős lehet ez a jellegzetesség kómás betegeknél, akiknél a betegség alatt nem váltható ki $\mathrm{EN}$, annak újbóli megjelenése a felépülés első megbízhatónak tűnő - jele lehet (KANE és munkatársai, 1993). Az EN mind normális, mind patológiás esetekben alkalmas a szenzoros-perceptuális képességek objektív mérésére. Elképzelhető, hogy lehetséges a zenei képességek felmérése (amennyiben ezt jellemzi a tiszta hangok elkülönítésének képessége), illetve cochleaimplantált betegeknél az alkalmazás sikerességének, azaz a normál beszédpercepció lehetőségének a felmérése (KRAUs és munkatársai, 1995). A módszer segítségével mód nyílik az afázia motoros és szenzoros komponensének finomabb elemzésére (CsÉPE, 1995; AALTONEN és munkatársai, 1993), diszfáziás (LANG és munkatársai, 1995) és a beszédpercepció zavaraival összefüggő tanulási rendellenességekben szenvedő gyermekek kiegészítő diagnózisára (KRAUs és munkatársai, 1995). Úgy tünik, hogy az EN alkalmas lehet különféle, a finom hallási feldolgozás mechanizmusait érintő károsodásokat okozó központi idegrendszeri betegségek hatásainak felmérésére. Az EN amplitúdójának csökkenése tapasztalható szkizofréneknél (JAVITT és munkatársai, 1995), Alzheimer-kórosoknál (PEKKONEN és munkatársai, 1994) és Parkinson-kórban szenvedőknél is (PEKKONEN és munkatársai, 1995). Az EN igen jelentős klinikai vizsgálati eszközzé válhat fiatal gyerekek esetében, mivel fiatal korban a központi idegrendszeri funkciók és károsodások egyetlen stabil kiváltott potenciál komponens jellemzőjének mutatkozik (CsÉPE, 
1995). Az eddigi eredmények szerint a módszer már csecsemőkortól használható vizsgálati célokra (ALHO és munkatársai, 1990).

A klinikai alkalmazás szempontjából igen kritikus kérdés, hogy a vizsgálatok ismétlése, több ülésben történő kivitelezése befolyásolja-e az EN paramétereit. Korábbi megbízhatósági vizsgálatokban azt tapasztalták, hogy az EN csoportszinten (azaz valamennyi kísérleti személy adatait átlagolva) jobban azonosítható, kisebb változatosságot mutat, mint egyénenként (PEKKONEN, RINNE, NÄÄTÄNEN, 1995; ESCERA, GRAU, 1996).

Kísérletünkben azt vizsgáltuk, hogy az akusztikus különbségekre az ismételt (szimulált klinikai) vizsgálatok körülményei között is megbizhatóan jelentkezik-e az EN; megfigyelhetők-e hosszú idejű habituációra, illetve tréningre utaló változások. E jelenségekről akkor beszélhetnénk, ha az EN latenciájában vagy amplitúdójában szisztematikus változások mutatkoznának: az ülések során egyre növekvő vagy csökkenő értékeket tapasztalnánk. Feltételezésünk egyrészt az volt, hogy az EN ellenáll a hosszú idejü habituációnak, valamennyi ülésben megbízhatóan, jól azonosíthatóan jelentkezik. Számítottunk bizonyos tréninghatás jelentkezésére (NÄÄTÄNEN és munkatársai, 1993), azt vártuk azonban, hogy ez a komponens azonosíthatóságát nem érinti negatívan.

Másodsorban azt vártuk, hogy a fonémaingerekre jelentkező EN válasz könynyebben azonosítható és megbízhatóbb lesz, mint a tiszta hangokra adott válasz. Ezt az elgondolást NÄÄTÄNen, SCHröger, Karakas, Tervaniemi és PAAVILAinen (1993), illetve Kraus, MCGee, Carrel és Sharma (1995) kísérleteire alapoztuk, azt feltételezve, hogy a fonémaingerekre adott EN-válasz kialakításában a beszéd elsajátítása során kialakult hosszú távú emlékezeti nyomok is szerepet játszhatnak. A tiszta hang ingerekre adott válaszban ilyen hosszú távú emlékezeti nyomok valószínúleg nem játszanak szerepet (bár komoly zenei müveltség esetén ez feltételezhető). A fonémaingerekre adott EN válasz nagyobb megbízhatóságának ismerete lényeges lehet a klinikai vizsgálatokban alkalmazott ingeranyag kiválasztásában.

\section{MÓDSZER}

Kisérleti személyek. Kísérletünkben tíz egészséges, ép hallású fiatal felnőttet (7 nő, 3 férfi) vizsgáltunk. Átlagéletkoruk 23 év volt (min.: 20, max.: 24 év).

Kisérleti elrendezés. A személyek öt ülésen vettek részt, melyek között 1-4 nap telt el. A kísérleti eljárás során sorozatokban adott hangokat alkalmaztunk. Egy kísérleti ülés hat ingerlési sorozatból állt. A sorozatok között rövid szünetet tartottunk.

Az egyes kísérleti sorozatok szerkezete az ún. „kakukktojás” (oddball) paradigma passzív változatának felelt meg, azaz a kísérleti személyeknek a tesztingerekkel kapcsolatos feladata nem volt. Figyelemelterelö ingerként a kísérleti személyek a hangingerek adása alatt hang nélküli videofilmet néztek. A „kakukktojás” kísérleti elrendezés azt jelenti, hogy számos azonos (standard) inger sorozatába kisebb számú eltérő (deviáns) inger illeszkedik. 
Ingerek. Az alkalmazott hangingerek három típusba tartoztak: tiszta hangok (T), magánhangzók (V) és mássalhangzóval kezdődő szótagok (C). Egy-egy kísérleti sorozatban 400 hanginger szerepelt, melyek mindig azonos típusba tartoztak. Típusonként egy standard és két deviáns ingert használtunk. A standard megjelenésének valószínüsége 70\%, a két deviáns ingeré 15-15\% volt. A három különböző ingertípust tartalmazó sorozatokból 2-2 fordult elő véletlenszerű sorrendben minden ülésben (összesen: $3 \times 2=6$ sorozat). A hangingerek hossza $200 \mathrm{~ms}$, intenzitása $70 \mathrm{~dB}$, az ingerek között eltelt idő (ISI) 1 másodperc volt. Egy sorozat 8 percig tartott. A hangingereket monaurálisan, jobb oldalon, fejhallgatóba adtuk.

1. táblázat. A kísérletben használt ingerek

\begin{tabular}{|l|l|l|l|}
\hline \multirow{2}{*}{ Gyakoriság $\rightarrow$} & \multicolumn{1}{|c|}{ Standard } & \multicolumn{1}{c|}{ Deviáns: kk. } & \multicolumn{1}{c|}{ Deviáns: nk. } \\
\cline { 2 - 4 } & \multicolumn{1}{|c|}{$70 \%$} & \multicolumn{1}{c|}{$15 \%$} & \multicolumn{1}{c|}{$15 \%$} \\
\hline Tiszta hang $(\mathrm{T})$ & $1000 \mathrm{~Hz}$ & $1050 \mathrm{~Hz}$ & $1200 \mathrm{~Hz}$ \\
\hline Magánhangzó $(\mathrm{V})$ & {$[$ é: $]$} & {$[\mathrm{i}:]$} & {$[\varnothing:]$} \\
\hline $\begin{array}{l}\text { Mássalhangzó-Magánhangzó } \\
\text { párok }(\mathrm{C})\end{array}$ & {$[\mathrm{ba}:]$} & {$[\mathrm{pa}:]$} & {$[\mathrm{ga}:]$} \\
\hline
\end{tabular}

A standard és deviáns ingereket a 1. táblázatban tüntettük fel. Típusonként az egyik deviáns kisebb mértékben (kk: kis különbség) tért el a standardtól, mint a másik (nk: nagy különbség). A magánhangzótípus két deviánsa a képzés módja, pontosabban nyelvállás (kk: [i:]) és ajakkerekítés (nk: [Ø:], azaz a magyar „ö” hang) szerint tért el a standardtól. A mássalhangzó-magánhangzó párok kialakításánál a hangzókészlet két lényeges eltérését, a zöngésség (kk: [pa:]) és a képzés helye (nk: [ga:]) szerinti eltérést vettük figyelembe. A beszédhangok (V és C típus) digitalizált természetes hangok voltak.

Az agyi bioelektromos jelek elvezetése és feldolgozása. A bioelektromos jelek elvezetésére a hajas fejbőrre ragasztott elektródák szolgáltak. A Medicor III. típusú elektródokat EC2 (Grass) elektródapasztával ragasztottuk a nemzetközi 10-20 rendszer szabályainak megfelelően. A komponensek biztos azonosítása érdekében elvezető elektródák kerültek az Fz, Cz, Pz, Fp1, Fp2, F3, F4, C3, C4, T3, T4, T5, T6, P3, P4, M1 és M2 pontokra. Referenciaelektródként az orra ragasztott elektródát használtunk. Földként a homlokra ragasztott elektróda szolgált. A szemmozgásokat a jobb szem fölé és alá (VEOG), illetve a szemek mellé jobb és bal oldalra (HEOG) ragasztott elektródákkal követtük. A jelek rögzítését az egyes ingerekkel kiváltott, eseményhez kötött potenciálok válogatását, átlagolását Neuroscan típusú hardware/software rendszerrel végeztük. A mintavételezési frekvencia $250 \mathrm{~Hz}$, a regisztráláskor alkalmazott szürési tartomány $\mathrm{DC}-70 \mathrm{~Hz}$ volt. Az átlagolás során a szemmozgás, izomfeszülés, illetve mozgás okozta mütermékeket egy rögzített szintű programmal szűrtük ki. A nyers válaszok átlagolása során alkalmazott ún. offline szürés 1-30 Hz tartományban történt. Az egységes EEG rögzítményt olyan 
idői ablakokra vágva dolgoztuk fel, amelyek az ingeradás előtti 50 ms-ot - ezzel meghatározva az alap jelszintet - és az ingeradás kezdete utáni 600 ms-ot tartalmazták. Az így nyert egységeket átlagoltuk.

Valamennyi kísérletben törekedtünk arra, hogy a tiszta mérési idő lehetőség szerint ne sokkal haladja meg az egyórányi időtartamot, mert bár a jel-zaj viszony alakulása szempontjából kedvezőbb, ha több ingert adunk, figyelembe kell venni a kísérleti személyek éberségében mutatkozó változásokat is.

Az EN-t az eltérő ingerek alkalmazásakor szokásos módon lehet láthatóvá tenni: a standard és deviáns ingerek által kiváltott, átlagolással kialakított hullámformák különbségét képezzük, azaz a deviáns ingerre adott átlagolt válaszhullámból kivonjuk a standard ingerre adott átlagolt válaszhullámot. Eredményül olyan görbét kapunk, amelyen a deviáns és a standard ingerekre adott válaszok közötti különbség látható.

A kapott válaszgörbék elemzése során alapvetően az agyi válaszok megjelenésének idejét (csúcslatenciáját) és azok csúcsamplitúdóját vettük figyelembe. A jellegzetes válaszhullámokat azok megjelenési tartományával, csúcslatenciájával, csúcsamplitúdójával, hullámformájával jellemezzük.

Statisztikai elemzés. Statisztikai elemzést az Fz, Cz, F3, F4, C3, C4 elvezetésekre végeztünk, mivel az EN itt jelenik meg a legnagyobb amplitúdóval. Az adatokat 3 és 2 szempontos (Feltétel $\times$ Ülés $\times$ Elektróda), összetartozó mintás (within-subject design) varianciaanalízissel (VA) elemeztük. Cohran-féle nem paraméteres Q-próbával vizsgáltuk, hogy az EN valamennyi mérés esetén egyaránt azonosítható volt-e. Az elemzéseket az SPSS 7.5 statisztikai programmal végeztük.

\section{EREDMÉNYEK}

Az adatfeldolgozás folyamán az EN csúcslatenciáját és csúcsamplitúdóját vettük figyelembe. A csúcsértékeket a regisztrátum 100-300 ms közötti legnegatívabb pontján mértük le. Az olvashatóság kedvéért a közlemény további részében a csúcsamplitúdó- és csúcslatencia-értékekre általában mint amplitúdó és latenciaértékekre hivatkozunk.

\section{Csoportszintü adatfeldolgozás}

A statisztikai próbák eredményei. A latencia- és amplitúdóértékek Feltétel $\times$ Elektróda szerinti bontásban számított csoportátlagai (az 1-5. ülésekben mért értékeket öszszeátlagolva) a 2. táblázatban láthatók. A varianciaanalíziseket az egyes Feltétel $\times$ Ülés $\times$ Elektróda kombinációkban adódó latencia- és amplitúdóértékeken hajtottuk végre.

Feltétel és Elektróda. A latenciaértékeken elvégzett 3 szempontos VA szerint a Feltétel hatása szignifikáns: $\mathrm{F}(5,45)>56,913(\mathrm{p}<0,001$, power $=1)$. Az Elektróda hatása is szignifikánsnak bizonyult: $\mathrm{F}(5,45)=3,788(\mathrm{p}<0,006$, power $=0,906)$. 
Valamennyi elektródára külön-külön is elvégeztünk egy 2 szempontos Feltétel $\times$ Ülés VA-t, ekkor a Feltétel hatása minden elektróda esetén: $F(5,45)>35,511$ $(\mathrm{p}<0,001$, power $=1)$. A 2. táblázatból kitűnik, hogy a latenciaértékek igen jól elkülönülnek az inger típusa szerint. A $\mathrm{C}$ és a $\mathrm{V}$ típusú ingereknél jóval nagyobb latenicaértékek találhatók, mint a T típusúaknál. A T típuson belül az 1200 Hz-es deviánsra gyorsabb a válasz (kisebb a latencia). Az amplitúdóértékek esetén a 3 szempontos VA egyik tényezője sem jelzett szignifikáns különbséget.

Ülés. Kérdésfelvetésünk az volt, hogy a mérések ismétlése szignifikánsan megváltoztatja-e az EN választ, esetleg megnehezíti-e annak azonosítását. A 3 szempontos VA szerint önmagában az Ülés hatása egyetlen elektródahelyen sem volt szignifikáns: $\mathrm{F}(4,36)=1,659,(\mathrm{p}<0,181$, power $=0,458)$. A Feltétel $\times$ Ülés interakció a latenciaértékek esetében szignifikáns volt: $\mathrm{F}(20,180)=2,484,(\mathrm{p}<0,001$, power $=0,997)$. A személyek közötti kontrasztok vizsgálata során azonban ez a hatás nem tűnt megbízhatónak, csak igen kevés Feltétel $\times$ Ülés $\times$ Elektróda kombinációban jelentkezett. A lehetséges $6 \times 5 \times 6=180$ (Feltétel $\times$ Ülés $\times$ Elektróda) esetből 10 alkalommal találtunk szignifikáns különbséget a személyek közötti kontrasztok vizsgálata során. 4 elektródahelyen $(\mathrm{Fz}, \mathrm{Cz}, \mathrm{F} 3, \mathrm{C} 4)$ az $1050 \mathrm{~Hz}-$ 2. Ülés; 4 elektródahelyen (Cz, F3, C3, C4) az 1200 Hz-1. Ülés kombinációban találtunk szignifikáns eredményt. A következetesen fellépő interakció tréningvagy habituációs hatásra utalna.

EKP görbék. A csoportátlaggörbék úgy készültek, hogy a 10 kísérleti személy mérési eredményeit valamennyi Feltétel $\times$ Ülés $\times$ Elektróda esetben külön-külön csoportosítva összeátlagoltuk. Az 1. ábrán az $1050 \mathrm{~Hz}$-es és a [ga:] feltétel standard és deviáns ingerére adott válaszokat, valamint a deviáns-standard kivonással előállított különbséggörbéket tüntettük fel. Az EN a különbséggörbéken 200 ms körüli csúccsal kiemelkedő hullám. A tiszta hang, illetve a beszédhang-inger alkalmazása különböző standard és deviáns válaszformához vezet. A tiszta hang feltételben a kb. 100-300 ms tartományban a deviáns ingerre adott válasz negatívabb, mint a standardra adott válasz, a standard és a deviáns inger esetében is jól kivehető az N1 (100 ms körüli hullám) válasz. Beszédhang esetén ettől eltérő a válaszmintázat.

A Típus és a Deviáns hatása. A 2. ábra valamennyi feltétel 1-3-5. ülésében bemutatja a különbséggörbéket. Jól észrevehetőek a különböző feltételekben kapott különbséggörbék közötti eltérések, amit a statisztikai próbák is jeleztek. Az EN vizuális azonosítása az [i], [pa:] és [ga:] helyzetben könnyebb. A [ga:] helyzetben különösen megkönnyíti az EN azonosítását a hullám előtti és utáni jellegzetes pozitivitás.

Az Ismétlés hatása. A 2. ábrán látható, hogy a különböző feltételekben kapott különbséggörbék EN hullámai meglehetősen átfedik egymást, különösen igaz ez a [pa:] és [ga:] feltételekben. 


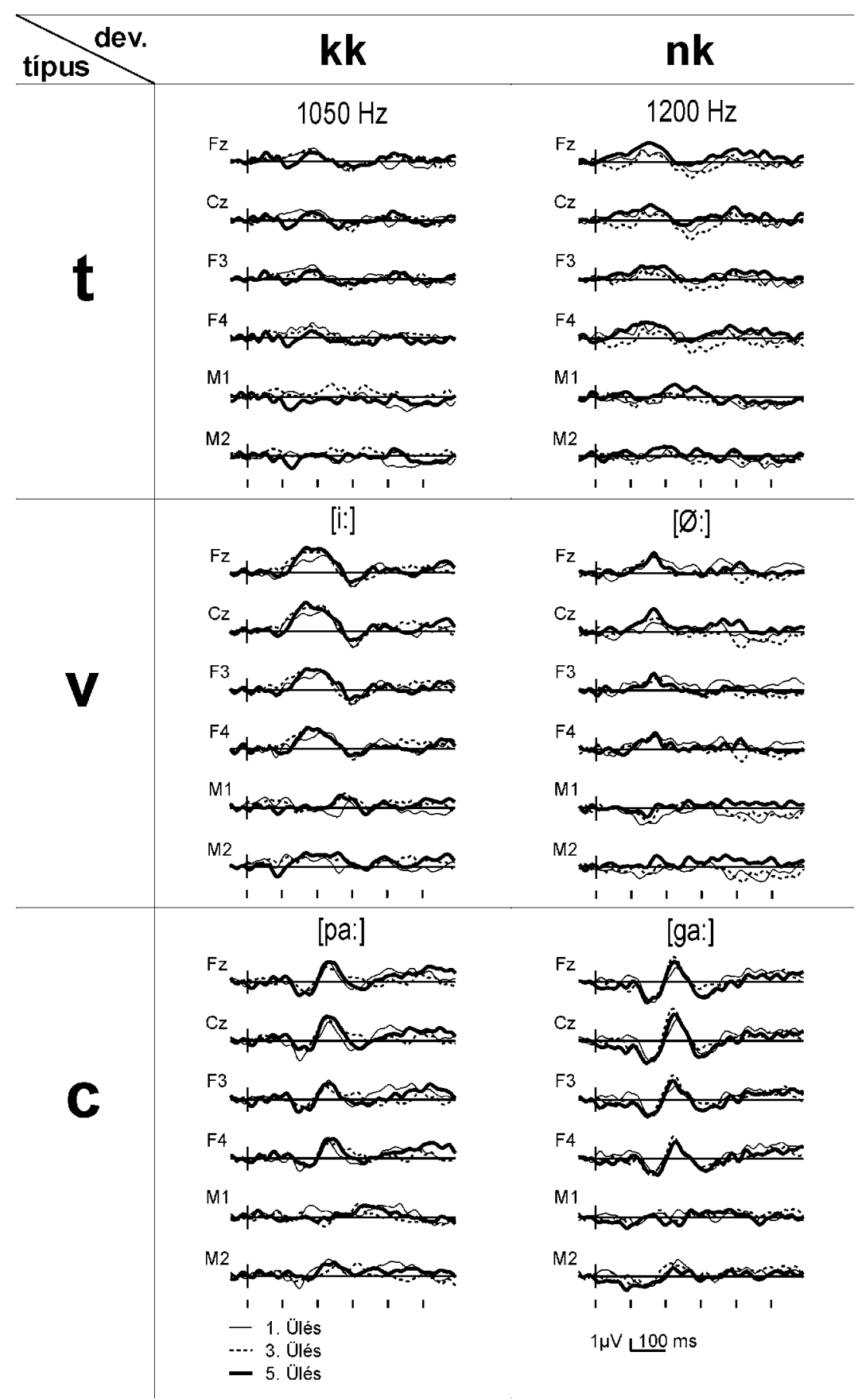

2. ábra. A deviáns-standard kivonással elóállított különbséggörbék az 1-3-5. ülésekben valamennyi Típus $\times$ Deviáns feltételben 


\section{Az adatok egyéni vizsgálata}

A csoportátlagokon valamennyi feltételben könnyedén felismerhető az EN válasz. Az EN azonban nem minden egyéni görbén azonosítható hasonló biztonsággal. Megvizsgáltuk, hogy mekkora biztonsággal azonosítható az EN, ha egy bizonyos (a gyakorlatban a megbízható felismerést lehetővé tevő) amplitúdószintet az EN megjelenése (azonosítása) kritériumának tekintünk. Az egyéni görbéken az EN azonosításának (elfogadásának) feltételéül szabtuk, hogy legalább mínusz $0,5 \mu \mathrm{V}$ csúcsamplitúdójú választ mérjünk a különbséggörbén az EN-ra jellemző idői megjelenési tartományban. A lehetséges nagy egyéni változatosság miatt eléggé széles, 120-300 ms közötti tartományban fogadtuk el az EN megjelenését. Amennyiben a mért amplitúdóérték nem érte el az azonosítási szintet, akkor úgy tekintettük, hogy az adott esetben nem jelent meg EN válasz.

Az elutasítások száma Feltétel $\times$ Ülés $\times$ Személy szerinti bontásban látható a 3. ábrán. Az elutasítások aránya (EuA) az 1-5. ülésekben rendre 22\%, 21\%, 16\%, $20 \%$ és $15 \%$ volt. Az átlagos EuA valamennyi feltételre $19 \%$ volt. A EuA gyakorta különösen magas volt egyes személyeknél (OG, SV, SD). Más személyeknél (BK, MF, SJ) ezzel szemben általában alacsony EuA mutatkozott. A Cohran-féle Qpróba szerint az elutasítások számát tekintve nem volt szignifikáns különbség az egyes ülések között.

A Feltétel $\times$ Ülés szerint bontott elfogadási arány (EfA) rendre $87 \%, 84 \%, 81 \%$, $81 \%$, 78\% és $74 \%$ volt az [i:], [ga:], [pa:], $1200 \mathrm{~Hz}, 1050 \mathrm{~Hz}$ és [Ø:] feltételben. Az átlagos EfA $81 \%(\mathrm{SD}=10,14 \%)$ volt. A Cohran-féle Q-próba szerint nem volt szignifikáns különbség a feltételek között.

A Cochran-féle Q-próba nem jelzett szignifikáns különbséget az elektródák között. Az EfA az [i:] feltételben az F3 és F4, a [ga:] feltételben a C3 és C4 elektródák esetében volt a legmagasabb.

A statisztikai tesztek nem jeleztek szisztematikus amplitúdó- és/vagy latenciaváltozásokat az egyes ülések között. Az EKP görbék gondos egyéni vizsgálata során megállapítottuk, hogy egy személy (FE) esetében a [ga:] feltétel kivételével valamennyi feltételben mutatkozik némi gyenge, habituációnak tekinthető hatás. MF esetében valószínűsíthetünk némi tréninghatást az $1050 \mathrm{~Hz}$ és [i:] feltételben.

\section{MEGBESZÉLÉS}

Csoportátlagok. Az EN a vizsgált elektródákon valamennyi kísérleti feltételben, mind az 5 ülésben jól elkülöníthető hullámként jelentkezett. A statisztikai elemzés szerint az EN amplitúdója stabilnak bizonyult, sem a Feltétel, sem az Ülés hatására nem változott. Tréning, illetve habituációs hatás (az Ülések mentén jelentkező szisztematikus latencia- vagy amplitúdóváltozás) nem mutatkozott statisztikailag számottevő mértékben.

Egyéni görbék. Kísérletünk legfontosabb célja az egyéni EN ülések mentén történő változásának vizsgálata volt. Az egyes személyek között nagy eltérések tapasztal- 
hatók az EN paramétereiben, és az EN válasz elfogadható voltában is. Az ülések túlnyomó többségében az EN a változások ellenére is csaknem valamennyi kísérleti személyben biztosan kimutathatónak bizonyult. Az átlagos elfogadási arány $81 \%$ volt. A legrosszabb egyéni azonosítási arány $60 \%$ körül alakult (2. ábra, OG és SV). Egy személy (OG) esetében csaknem valamennyi esetben az átlagosnál több elutasításra volt szükség. Ennek alapján elképzelhető, hogy az EN személyenként változó sikerrel azonosítható. Felmerül a kérdés, hogy az EN ugyanekkora sikerrel azonosítható-e idősebb személyek esetén is, tekintve, hogy az EN mutat bizonyos életkori változásokat (CZIGLER és munkatársai, 1992).

A csoportátlagokra és egyéni értékekre vonatkozó megállapításaink összhangban vannak az EN reprodukálhatóságára vonatkozó korábbi eredményekkel, azaz az EN paraméterei csoportszinten kevésbé változnak (PEKKONEN és munkatársai, 1995; EsCERA, GRAU, 1996). Meg kell említeni, a korábbi megbízhatóságvizsgálatokban magasabb volt a standard és alacsonyabb a deviáns ingerek aránya (standard: 85\%, deviáns: 15\%; valamint 92 és 8\%), illetve csupán egy, és nem két deviánst használtak. Kísérletünkben tehát az EN kiváltására nézve kedvezőtlenebb feltételek mellett (NÄÄTÄNEN és munkatársai, 1983) sikerült jó megbízhatósági eredményeket kimutatni. A standard ingerek arányának emelésével valószínúleg növelni lehet az EN megbízhatóságát, amennyiben pedig elegendő, érdemes csupán egy deviáns ingert használni, ekkor a deviáns inger kisebb megjelenési valószínűsége miatt nagyobb EN váltható ki. Deviánsként azt az ingertípust érdemes választani, amelyikkel a legmegbízhatóbban váltható ki az EN.

A kisérleti feltételek összevetése. Melyik kísérleti feltételben lehetett az EN-t a leginkább megbízhatóan kimutatni? Az EN-t általában tiszta hangokkal váltják ki. Kísérletünkben a statisztikai eredményeink szerint nem volt különbség a különböző ingerek által kiváltott EN amplitúdója között. A görbék elemzése során azt találjuk, hogy vizuálisan az [i:], [ga:] és [pa:] feltételben azonosítható könnyebben az EN. A C ingertípus esetén különösen megkönnyíti az EN azonosítását a latenciák kicsiny szórása, illetve a [ga:] feltételben a hullám előtti és utáni kifejezett pozitivitás (2. táblázat; 2. ábra). Az elutasítások aránya az [i:] és a [ga:] feltételben volt a legalacsonyabb, bár a különbség nem szignifikáns.

Kezdeti felvetésünket, miszerint a beszédhangok esetében váltható ki a legnagyobb megbízhatósággal az EN, statisztikailag nem tudtuk igazolni. Nem tudtuk tehát egyértelmüen alátámasztani azokat az elméleteket, amelyek azt feltételezik, hogy a beszédhangokra adott EN nem csupán az aktuális ingerlési folyamat során

3. ábra. Az elutasítások száma Személy $\times$ Feltétel $\times$ Ülés szerinti bontásban

A vízszintes tengelyen a 10 kísérleti személy monogramja látható. A függóleges tengelyeken az elutasítások száma, illetve az összes méréshez viszonyított aránya olvasható le. (Egy személynek egy ülésben, egy feltételben, 6 elektródán mért adatait vizsgáltuk. Egy ülésben, 6 feltételben tehát az elutasítások lehetséges csúcsértéke $6 \times 6=36$ eset $=100 \%$.) Az egyes oszlopok az adott személynél adott ülésben megállapított elutasítások számát jelentik. Az oszlopok különböző színű részei az egyes feltételekben kapott elutasításokat jelképezik (lásd jobb oldali jelmagyarázatot). A vastag szaggatott vonal az átlagot, a vékonyabb folytonos vonalak a szórást jelképezik. Az „1-5. Ülés” feliratú ábra az öt ülés összesített adatait tartalmazza. 
megjelenő standard ingerek hatására keletkező memórianyomokra épül (NÄÄTÄNEN, 1995). A görbék áttekintése során jelentős, ámde statisztikailag nem szignifikáns amplitúdókülönbségek láthatóak a tiszta hangok és a beszédhangok között. Ezeknek a lehetséges különbségeknek a pontos statisztikai felméréséhez nagyobb mintán végzett vizsgálatra lenne szükség. Kérdéses, hogy ezek a különbségek a beszédhangok „erőteljes” emlékezeti reprezentációjának, vagy egyszerüen csak a tiszta hangok és a beszédhangok fizikai felépítésének következményei. Elképzelhetô, hogy összetettebb beszédhangok esetében általában fizikailag is nagyobb a standard ingertől való eltérés. Ez utóbbi feltevést támasztja alá, hogy kísérletünkben jelentősen különbözött a két magánhangzó-ingerre adott válasz. A két V típusú ingerre egymáshoz jóval hasonlóbb válaszokat vártunk. Feltehetô, hogy az [i:] deviáns fizikailag nagyobb mértékben tér el az általunk használt standardtól, mint az [Ø:] deviáns.

Összegzés. Az EN csoportszinten megbízható. Az egyéni EN válaszban nagy különbségek tapasztalhatók. Az általunk használt $-0,5 \mu \mathrm{V}$-os kritériumszint esetén az EN egyéni elfogadása $60-81 \%$ között alakult. Az EN megbízhatósága a standard ingerek arányának emelésével és az ingertípus gondos megválasztásával nagy valószínűséggel tovább fokozható.

\section{IRODALOM}

Aaltonen, O., Tuomainen, J., Laine, M., Niemi, P. (1993) Cortical differences in tonal versus vowel processing as revealed by an ERP component called mismatch negativity (EN). Brain and Language, 44, 139-152.

Alho, K., SAino, N., SAjaniemi, N., Reinikainen, K., NäÄtÄnen, R. (1990) Event-related brain potential of human newborns to pitch change of an acoustic stimulus. Electroencephalography and clinical Neurophysiology, 77, 151-155.

Cowan, N., Winkler, I., Teder, W., NÄÄTÄnen, R. (1993) Memory prerequisites of the mismatch negativity of the auditory event-related potential (ERP). Journal of Experimental Psychology: Learning, Memory, and Cognition, 19, 909-921.

Czigler, I., Csibra, G., Csontos, A. (1992) Age and interstimulus interval effect on event related potentials to frequent and infrequent auditory stimuli. Biological Psychology, 33, 195-206.

Csépe, V. (1995) On the origin and development of the mismatch negativity. Ear and hearing, 16, 91-104.

CsÉPe, V., MOLnÁr, M. (1997) Towards the possible clinical application of the mismatch negativity component of the event-related potentials. Audiology and Neuro-Otology, 2, 354-369.

ESCERA, C., GRAU, C. (1996) Short-term replicability of the mismatch negativity. Electroencephalography and Clinical Neurophisiology, 6, 549-554. 
Javitt, D. C., Doneshka, P., Grochowski, S., Ritter, W. (1995) Impaired mismatch negativity generation reflects widespread dysfunction of working memory in schizophrenia. Arch Gen Psychiatry, 7, 550-558.

Kane, N. M., Curry, S. H., Buttler, S. R., Cummins, D. H. (1993) Electrophysiological indicator of awakening from coma. The Lancet, 341, 688.

Kraus, N., McGee, T., Carrel, T. D., Sharma, A. (1995) Neurophysiologic bases of speech discrimination. Ear and Hearing, 1, 19-37.

Lang, A. H., Eerola, O., Korpilahti, P., Holopainen, I., Salo, S., Uusipaikka, E., Aaltonen, O. (1995) Clinical applications of the mismatch negativity. Ear and Hearing, $16,117-129$.

NÄÄTÄTEN, R. (1986) The orienting response theory: An integration of informational and energetical aspects of brain function. In Hockey, R., Gaillard, A. W. K., Coles, M. (eds) Energetics and human information processing. 91-111. Martinus Nijhoff, Dordrecht

NÄÄTÄNEN, R. (1990) The role of attention in auditory information processing as revealed by event-related potentials and other brain measures of cognitive function. Behavioral and Brain Sciences, 13, 201-288.

NÄÄTÄNEN, R. (1992) Attention and brain function. 136-206. Erlbaum, Hillsdale

NÄÄTÄNEN, R. (1995) The Mismatch Negativity: A powerful tool for cognitive neuroscience. Ear and Hearing, 16, 6-18.

NÄÄTÄnen, R., Alho, K. (1997) Mismatch Negativity - The measure for central sound representation accuracy. Audiology and Neuro-Otology, 2, 341-353.

NÄÄtÄnen, R., Gaillard, A. W. K., Mantysalo, S. (1978) Early selection effect reinterpreted. Acta Psychologica, 42, 313-329.

NäÄtÄnen, R., Sams, M., JÄrvilehto, T., Soininen, K. (1983) Probability of deviant stimulus and event-related brain potentials. In Sinz R., Rosenzweig, M. R. (eds) Psychophysiology, 1980, 397-405. VEB Gustav Fischer Verlag, Jena

NäÄtänen, R., Schröger, R., Karakas, S., Tervaniemi, M., PaAvilainen, P. (1993) Developement of a memory trace for a complex sound in the human brain. NeuroReport, 4 , 503-506.

Pekronen, E., Jousmaki, V., Kononen, M., Reinikainen, K., Partanen, J. (1994) Auditory sensory memory impairment in Alzheimer's disease: An event related potential study. Neuroreport, 18, 2537-2540.

Pekronen, E., Jousmaki, V., Reinikainen, K., Partanen, J. (1995) Automatic auditory discrimination is impaired in Parkinson's disease. Electroencephalography and Clinical Neurophysiology, 1, 47-52.

Pekkonen, E., Rinnie, T., NäÄTÄNEn, R. (1995) Varibility and replicability of the mismatch negativity. Electroencephalography and Clinical Neurophisiology, 6, 546-554.

SAms, M., Alho, K., NäÄTÄnen, R. (1983) Sequential effects in the ERP in discriminating stimuli. Biological Psychology, 17, 41-58. 


\title{
REPLICABILITY OF MISMATCH NEGATIVITY TO DIFFERENT ACOUSTIC PARAMETERS
}

\author{
SZÜCS, DÉNES-CSÉPE, VALÉRIA-SÜLE, JUDIT
}

Our question was whether repeated-simulated clinical-measurements carried out in several sessions have an effect on the main characteristics of MMN. From the point of view of clinical and any other applications it is of crucial importance in what measure the MMN resists long-term habituation, or if some training effect can be demonstrated. The subjects were 10 healthy young adults. A passive oddball experimental paradigm was used with tone, vowel and consonant-vowel (CV) syllables as stimulus types. There were two deviant stimuli in each stimulus type: large and small difference from the standard. The probability of the standard was 70\%, that of the deviants 15-15\%. Each subject participated in 5 measurements in 1-4 day intervals. The test-retest reliability in the course of the 5 measurements was analyzed both on the group and on the individual level.

The group-level MMN was highly reliable in all conditions. There were large differences in the individual MMN. In the individual data analysis all the responses more positive than $-0.5 \mu \mathrm{V}$ were discarded. By this criterion-level the individual MMN could be accepted in the range of 64-90\% of all cases (mean: 81\%). The reliability of the different stimulus types did not differ significantly. No significant training or habituation effects were found. The reliability of the MMN can possibly be further improved by carefully selecting the stimuli and increasing the probability of the standard stimulus.

Key words: $\quad$ mismatch negativity, automatic stimulus processing, replicability, habituation, sensitization 